\title{
POLA PENYEBARAN SEL MUKUS PADA SALURAN PENCERNAAN IKAN TAWES (Punctius javanicus)
}

\section{DISTRIBUTION PATTERN OF MUCUS CELL ON DIGESTIVE TRACT OF JAVA CARP (Punctius javanicus)}

\author{
Cahyono Purbomartono*), Priyo Susatyo ${ }^{* *}$, dan Arif Setiawan ${ }^{* *}$
}

\begin{abstract}
This research was conducted on digestive system of Java carp (Puntius javanicus). Gut of fish samples was processed for histological preparation, stained with periodic acid shiff's (PAS) staining.

The results of this research showed that the properties of mucus cells in the digestive tract of Java carp was comprised of goblet cells. The total number of goblet cells in the mid gut was higher than that of in the foregut and hindgut. Morphology of goblet cells in the foregut and hindgut was round in shape but spherical on the midgut.
\end{abstract}

\section{Key words : Digestive tract, goblet cells, Java carp, mucus cell}

\section{Pengantar}

Ikan tawes (Puntius javanicus) merupakan komoditas perikanan air tawar yang memiliki habitat asli Indonesia. Ikan ini dikenal pula sebagai ikan putihan, bader atau mas jawa. Di Inggris jenis ikan tawes disebut sebagai java carp. Ikan tawes menyukai hidup pada perairan deras dan termasuk golongan herbivora (Susanto, 1999).

Populasi ikan tawes di perairan umum maupun yang dibudidaya saat ini cenderung kurang berkembang. Kondisi ini dapat disebabkan antara lain banyaknya sungai yang mengalami pendangkalan serta adanya "komoditas baru" yang lebih produktif. Namun demikian, biasanya ikan hasil persilangan lebih rentan terhadap penyakit dibanding dengan ikan lokal yang masih galur murni. Ikan tawes yang ada di Indonesia umumnya masih merupakan jenis ikan lokal yang masih menunjukan sifat-sifat kemurniannya. Pada keadaan ikan yang masih berada dalam habitat alamiahnya, maka sistem pertahanan luarnya (pada mukus) lebih tahan terhadap serangan penyakit maupun lingkungan yang kurang baik dengan membentuk "physical barier" yang telah teradaptasi (Playle and Wood,
1989). Mukus diihasilkan oleh sel mukus atau sel goblet yang biasanya terdapat pada kulit, saluran pernafasan serta saluran pencernaan yang berfungsi untuk melapisi bagian luar tubuh ikan (Asakawa, 1970).

Pada saluran pencernaan, mukus sangat berperan didalam membantu pencernaan dan melindungi lapisan luar dari usus terhadap infeksi bakteri dan virus (Allen, 1981). Mukus mengandung substansi seperti imunoglobulin (Rombout et.al., 1995), lisozym (Fletcher and White, 1973), C-reactive protein (Ramos and Smith, 1978) serta lektin (Suzuki, 1995). Substansi tersebut sangat penting untuk pertahanan penyakit maupun lingkungan yang tidak menguntungkan (Jones et.al., 1975. Pada beberapa spesies ikan, jenis maupun jumlah sel mukus dapat berbedabeda. Bahkan pada organ yang sama, jenis serta jumlah sel mukus juga dapat berbeda yang disebabkan karena kandungan glikoprotein penyusun mukusnya tidak sama (Yamada and Yokote, 1975).

Penelitian ini bertujuan untuk mengetahui pola penyebaran sel mukus yang terdapat pada saluran pencernaan. Adanya variasi makanan yang masuk, memberikan stimuli terhadap sel-sel epitel maupun sel

\footnotetext{
"Fakultas Perikanan dan IImu Kelautan, Universitas Muhammadiah Purwokerto, Jl. Raya Dukuhwaluh PO BOX 102 Purwokerto 53182

${ }^{* *}$ Fakultas Biologi, Universitas Jenderal Sudirman Purwokerto, Jl. Dr. Suparno Karangwangkol Purwokerto
} 
mukus untuk memberikan respon terhadap jenis maupun konsistensi dari makanan yang masuk tersebut. Hal ini yang dapat menyebabkan adanya perbedaan penyebaran sel mukus serta jenis dan jumlahnya dalam suatu jaringan maupun organ.

\section{Bahan dan Metode}

Materi yang digunakan dalam penelitian ini berupa ikan tawes ukuran konsumsi. Bahan-bahan lainnya berupa minyak cengkih untuk anastesi, serta bahanbahan untuk preparat histologis serta pengecatan PAS (etanol, aquades, parafin, canada balsam, xylol, larutan reagen shiff's, larutan periodic acid dan hematoxylen). Sedangkan peralatan yang digunakan meliputi: alat-alat bedah, objec glass, staining jar, mikrotom, inkubator, cover glass dan mikroskop.

Ikan tawes diberi anastesi dengan minyak cengkih hingga pinsan. Setelah pinsan, ikan dibedah untuk diambil bagian ususnya. Usus dipotong kecil secara melintang pada usus bagian depan, tengah dan belakang, kemudian dimasukkan dalam larutan formalin $10 \%$ selama 24 jam. Setelah difiksasi selama 24 jam, potongan kecil dari usus tersebut dicuci dengan etanol. Proses selanjutnya adalah:

- dehidrasi sampel, dengan memasukkan potongan kecil usus kedalam seri konsentrasi etanol dari konsentrasi yang rendah ke tinggi.

- dealkoholisasi dengan memasukkan potongan usus tersebut kedalam etanol-xylol, sampai kemudian dalam xylol murni.

- infiltrasi parafin-xylol secara berseri sampai dengan parafin murni

- embedding atau penyelubungan dengan parafin

- pengirisan dengan mikrotom

- penempelan pada objek glass serta pencucian

- perendaman dalam periodik acid selama 7 menit

- pencucian dengan air mengalir
- perendaman dalam reagen shiff's selama 15 menit

- pencucian dalam air mengalir selama 5 menit

- perendaman dalam hematoxylen selama 1 menit dan pembersihan dengan alkohol $96 \%$

- pengeringan dan penutupan objek glass dengan canada balsam

- pengamatan di bawah mikroskop yang meliputi jenis sel mukus, morfologi serta jumlah sel mukus pada masing-masing bagian usus

\section{Hasil dan Pembahasan}

Hasil pengamatan menunjukkan, bahwa villi pada usus bagian depan ikan tawes lebih ramping, panjang dan lebih jarang dibandingkan dengan villi pada bagian usus tengah maupun belakang. Sedangkan pada usus bagian tengah, mempunyai villi yang lebih pendek, lebih rapat dan tebal dibanding usus depan. Jumlah sel mukus pada usus bagian tengah juga lebih banyak dibandingkan sel mukus pada usus bagian depan. Sedangkan pada usus bagian belakang dari ikan tawes, tidak memiliki villi dan hanya memiliki sedikit sel mukus (Tabel 1).

Secara umum dapat dinyatakan bahwa pada saluran pencernaan dari ikan tawes dilapisi dengan mukus yang dihasilkan oleh sel-sel goblet. Menurut Teraoka (2000), lapisan mukus yang terdapat pada saluran pencernaan ikan berguna untuk perlindungan dari sekresi asam lambung $(\mathrm{HCl})$ yang diproduksi oleh lambung dan kemudian terbawa ke usus. Mukus mampu menetralisir $\mathrm{HCl}$ karena mukus mengandung bikarbonat yang bersifat basa (Sharps, 1982). Menurut Barry (2002), pencernaan pada ikan jenis herbivora lebih mengandalkan pada kerja bakteri-bakteri flora yang terdapat pada saluran pencernaannya. Umumnya jenis ikan herbivora ini lebih sedikit dalam mensekresi enzim dibandingkan pada kelompok ikan dari jenis karnivora. 
Tabel 1. Penyebaran sel mukus pada saluran pencernaan ikan tawes.

\begin{tabular}{|c|c|c|c|}
\hline Letak Usus & Jenis sel & Bentuk sel & Jml sel/bidang pandang \\
\hline \multirow[t]{4}{*}{ Bagian depan } & 1. goblet & 1. bulat & 29 \\
\hline & goblet & bulat & 34 \\
\hline & goblet & bulat & 31 \\
\hline & & & rerata : \\
\hline \multirow[t]{4}{*}{ Bagian tengah } & goblet & batang & 44 \\
\hline & goblet & batang & 42 \\
\hline & goblet & batang & 47 \\
\hline & & & rerata : \\
\hline \multirow[t]{4}{*}{ Bagian belakang } & goblet & bulat & 21 \\
\hline & goblet & bulat & 23 \\
\hline & 3. goblet & bulat & 22 \\
\hline & & & rerata : \\
\hline
\end{tabular}

Sedangkan pada karnivora, menurut Dellman (1992), aktivitas pencernaannya memerlukan banyak sekresi enzim. Sekresi enzimatis ini menyebabkan usus menstimuli sel goblet dalam memproduksi mukus yang lebih banyak untuk melindungi lapisan luar dari usus terhadap kerusakan mekanik dan iritasi. Ingram (1980) menyatakan, mukus mampu melindungi saluran pencernaan dari reaksi enzimatis karena didalam mukus terdapat $\mathrm{C}$-reaktif protein yang berfungsi sebagai pelindung terhadap reaksi kimia. Selanjutnya disebutkan oleh Bowen (1998), substansi mukus dapat membentuk "sugar coating" atau lapisan gula pada usus yang berfungsi untuk melindungi lapisan permukaan usus dari reaksi proteolisis. Namun pada kelompok herbivora seperti pada ikan tawes, cenderung terjadi suatu penandukan pada lapisan ususnya. Hal ini disebabkan, sel-sel epitel pada lapisan luar saluran pencernaan beradaptasi dengan makanan yang relatif kasar berupa serat-serat dari tumbuhan yang dimakannya (Dellman, 1992).

Perbedaan lingkungan atau habitat suatu ikan juga dapat berpengaruh terhadap jumlah sel goblet maupun jenis mukus yang dihasilkannya. Pada ikan yang yang hidupnya menyukai pada bagian dasar perairan yang kotor/keruh, cenderung memiliki sel goblet yang lebih banyak (Sutarman, 2000). Sel-sel goblet ini memproduksi mukus yang diperlukan untuk melindungi dirinya dari pengaruh lingkungan yang buruk maupun terhadap bahan pencemar dengan cara membentuk "physical barier" (Hoer, 2000). Lain halnya dengan ikan tawes yang bersifat herbivora dan lebih suka hidup pada perairan yang deras, sehingga jumlah sel goblet relatif sedikit (Gas and Noailliac-Depeyre, 1976).

\section{Kesimpulan}

1. Sel mukus yang terdapat pada ikan tawes merupakan jenis sel goblet

2. Sel goblet lebih banyak terdapat pada usus bagian tengah dari pada di bagian depan dan belakang

3. Bentuk sel goblet pada bagian usus bervariasi, usus bagian depan berbentuk bulat, bagian tengah berbentuk batang dan pada bagian belakang berbentuk bulat.

\section{Daftar Pustaka}

Allen, A. 1981. Structure and function of gastrointestinal mucus. In: L.R. Johnson (Ed.). Physiology of the gastrointestinal tract. New York: Raven Press. 302 p.

Asakawa, M. 1970. Histochemical studies of the mucus. In: L.R. Johnson (Ed.). Physiology of the gastrointestinal tract. New York: Raven Press. 36:83-87.

Bavelander, G and J. Ramaley. 1988. Dasar-dasar histologi. Penerbit Erlangga. Jakarta. 128 p.

Barry, G. 2002. The design of our digestive enzymes today. 
http://www.second-opinions.co.uk/ carn herb comprison.html. Diakses tanggal 23 Juni 2004.

Bowen, R. 1998. Mucus and mucin. http://article.dphnet.com/cat-02/ biology.html. Diakses tanggal 19 Mei 2004.

Dellman, B. 1992. Histology veteriner II. UI Press. Jakarta. 174 p.

Fletcher, T. C. and A. White 1973. Lysozyme activity in the plaice (Pleuronectes platessa L.). Experientia 29: 1283-1285.

Gas and Noailliac-Depeyre. 1976. Studies on intestinal epithelium involution during prolonged fasting. J. Ultrastructure. Res. 56: 137-151.

Hildebrant, M. 1989. Analysis of vertebrae structure. New York Academic Press. USA.

Hoar, W. S. 1989. Fish physiology. New York Academic Press. USA.

Hoer, F. J. 2000. Intestinal integrity and the impact of lossing it. http:// poultry-health.com/for a/inthelth/ hoer 01.htm. Diakses tanggal 24 Juni 2004.

Ingram, G. A. 1980. Natural imunity in fish. J. Fish Biology, 16: 46-60.

Jones, R. and L. Reid. 1975. The effect of $\mathrm{pH}$ on alcian blue staining of epithelial acid glyco-proteins I. Sialomucins and Sulpho-mucins (singly or in simple combination). Histochem J. 5:9-18.

Playle, R. C. and C. M. Wood. 1989. Water chemistry changes in the gill micro-environment of rainbow trout: experimental observations and theory. J. Comparative Biology. 159: 527-537.
Ramos, F. and A.C. Smith. 1978. The Creactive protein (CRP) test for the detection of early disease in fishes. Aquaculture. 14:261-266.

Rombout, J. H. W. M., M. Taverne, Van de Kamp and A. J. Taverne-Thiele. 1995. Differences in mucus and serum immunoglobulin of carp (Cyprinus carpio L). Developmental and Comparative Immunology. 17: 309-317.

Sharp, J. 1982. Cells, organs, and animals :An approach to the basic medical sciences. Blackwell Scientific Publication Oxford. London. 62 p.

Susanto, H. 1999. Usaha pembenihan dan pembesaran tawes. Penebar Swadaya. Jakarta. $71 \mathrm{p}$.

Sutarman. 2000. Teknik budidaya ikan lele dumbo. Sinar Baru Algensindo Offset. Bandung. $78 \mathrm{p}$.

Suzuki, Y. 1995. Deffence mechanism in the skin of fish. In: K. Mori and $\mathrm{H}$. Kamiya (Eds.) Defense mechanism in aquatic animals, Koseisya Koseikaku, Tokyo. 9-17.

Teraoka, H. 2000. $\mathrm{Ca}^{2+}$ signaling in porcine duodenal glands by muscarinic receptor activation. http://ajpgi.physiology.org/cgi/conte nt/full/280/4/G729. Diakses tanggal 16 Mei 2004.

Yamada, K and M. Yokote, 1975. Morphochemical analyisis of mucosubstances in some epithelial tissues of the cel (Anguilla japonica). Histochemistry. 43: 161172. 